\title{
Contribution of Principal Transformational Leadership and Interpersonal Communication through Work Motivation on Teacher Performance at all State Junior High Schools in Banjarmasin Utara Sub-district
}

\author{
Muhammad Ruslan *, Sulaiman, Suhaimi \\ Master Program of Education Management, Universitas Lambung Mangkurat, Banjarmasin 70123, Indonesia
}

\section{Article history:}

Submission August 2020

Revised September 2020

Accepted October 2020

*Corresponding author:

E-mail: mruslanregb@gmail.com

\begin{abstract}
Teacher performance is very crucial in realizing the vision and mission of the school. Therefore, this study aims to analyze the contribution of transformational leadership and interpersonal communication to teacher performance through teacher work motivation. This research uses a descriptive quantitative method. The research sample of 171 people is from 299 teachers spread in 10 state junior high schools in North Banjarmasin District. The research was using a questionnaire to collect the data that has been proven valid and reliable. Furthermore, the collected data were analyzed using Path Analysis techniques. From the data analysis done, the results of this study indicate that: (1) There is a direct contribution between transformational leadership, interpersonal communication, work motivation, and Teacher performance. Moreover, (2) there is an indirect contribution between transformational leadership, interpersonal communication through work motivation as a variable intermediary on teacher performance in all State Junior High Schools in Banjarmasin Utara Sub-district. This study concludes a significant effect of all the independent variables studied both directly and indirectly.
\end{abstract}

Keywords: Transformational leadership, interpersonal communication, work motivation, teacher performance

\section{Introduction}

Performance is essential in efforts to achieve a goal. According to Uhar (2010), a person's performance is shown from the activities or implementation of the tasks carried out. The intended results include the method or process and the quality of the output from carrying out the activity or task. In general, employees' performance will affect the success and growth of an institution (Vosloban, 2012). Besides, employees' performance, shown in the ability of employees to carry out their duties, will also significantly affect the institution's performance in achieving its vision (Toumi et al., 2005).

Specifically, in the world of education, Yuniarsih \& Suwanto (2008) explain that a teacher's performance is related to the abilities and results of what the teacher does, which includes making lesson plans and implementing and evaluating learning. As per the Government Regulation no. 74 of 2008 concerning Teachers, Article 52 which states that the teacher's workload includes the main activities: (a) planning learning; (b) carry out learning; (c) assess learning outcomes; (d) guiding and training students, and (e) carry out additional tasks attached to the implementation of main activities per the teacher's workload. Like the performance of employees in a company, teacher performance also has a vital role in achieving the school's vision. Teachers' performance is significant in the teaching and learning process because everything that the teacher does during the learning process will affect student achievement in both academic and non-academic fields (Blazar \& Kraft, 2017). So, it can be said that the better the teacher's performance, the better student achievement (Poenamawijaya et al., 2018). Given the importance of teacher performance in schools,

\section{How to cite:}

Ruslan, M. (2020). Contribution of principal transformational leadership and interpersonal communication through work motivation on teacher performance at all state junior high schools in Banjarmasin Utara Sub-district. Journal of K6, 
teacher performance should receive special attention. Efforts in improving teacher performance are essential to implement so that the quality of learning and student learning outcomes improve. To determine the right effort to improve teacher performance, accurate and empirically proven information is needed on what things can affect a teacher's performance.

Theoretically, one of the factors that can affect a teacher's performance is the teacher's work motivation. Motivation is the driving force which results in an organization member willingness to mobilize abilities, such as expertise or skills, energy and time to carry out various activities in the scope of their responsibility and fulfill obligations to achieve the goals and objectives of the organization that have been predetermined (Siagian, 2012).

A person with high work motivation will also have a high commitment to the work they do (Ofojebe \& Ezugoh, 2010). It happens because someone who has high work motivation will not give up quickly, and most of them have found clear reasons why they are doing something or doing the job (Beltrán-Martín \& Bou-Llusar, 2018).

When brought to the context of education, teachers who have high work motivation, of course, also have high commitment and enthusiasm so that they will work and carry out all their duties as well as possible. So, it can be said that work motivation plays a vital role in influencing the level of a teacher's ability to carry out his duties and functions (Kemelimeda et al., 2018). Therefore, if all teachers carry out their duties as well as possible, in the end, it will affect the teaching and learning process and can improve student achievement.

Work motivation has a close relationship with performance. Thus, it can be understood that if the work motivation is low, it will result in low performance, even though it has functional abilities and opportunities. Motivation can come from within oneself (internal motivation) and from outside oneself (external motivation) (Uno, 2011). Right work motivation, when the motivation arises in a person to do activities. Teachers who have high work motivation, of course at work, will carry out all their duties as well as possible, which in turn will affect the teaching and learning process and can improve student learning achievement. Likewise, if the work motivation is high, but if the opportunity to use his abilities is none, then the performance will also become low. Alternatively, if the work motivation is high and the opportunity has present, but if the ability is zero, then the performance will also become low. Herzberg (2017) proposes a theory of motivation based on a theory of two factors: motivating factors and hygiene factors.

Apart from motivation, another important factor in supporting teacher performance is the communication process in the school environment where the teacher works. Quality interpersonal communication is vital in an organization (Wibowo, 2014). Effective communication will make it easier for someone to carry out their duties. Effective communication will provide a channel for the management process to provide information and build understanding and commitment with staff in an organization (Suriansyah A., 2014). With the creation of excellent communication, every problem will be adequately resolved, because, in principle, communication is to find consensus as a win-win solution to various problems (Ramdhani \& Suryadi, 2005). Interpersonal communication is influenced by several factors, namely openness, empathy, support, positivity, balance, confidence, freshness, interaction management, disclosure, and orientation to others (Surya, 2003).

According to DeVito (2013), interpersonal communication contains several elements, namely: (1) The nature of openness which designates at least two aspects of interpersonal communication. The first aspect that we must be open to the people we interact with. We do not necessarily have to share all the backgrounds of our lives. The second aspect is our willingness to respond to others honestly and frankly about everything he says and vice versa; (2) Empathy is a person's ability to know what is happening to other people at a particular time. Emphatic People are capable of understanding other people's experiences, feelings, and attitudes and their hopes and desires for the future; (3) A supportive attitude is an attitude that reduces defensiveness. This attitude arises when the individual cannot accept, is dishonest, and has no empathy; (4) A positive attitude is interpersonal communication fostered when people have a positive attitude towards themselves and others. A positive attitude can be shown by a variety of behaviors and attitudes, including respect for others, 
positive thinking towards others, not overly suspicious, believing in the importance of others, giving praise and appreciation, and commitment to collaborating; and (5) Equality in interpersonal communication includes two things. The first is the similarity in the field of experience among communication actors. The two have similarities in giving and receiving messages.

Another factor that is also important in improving teacher performance is the principal's leadership pattern. When viewed from its function, a school principal is responsible for carrying out educational activities, school administration, coaching other educational personnel, and utilizing and maintaining facilities and infrastructure (Mulyasa, 2004). It is that the principal has a critical role in ensuring that the education process in schools runs well. Thus, ensuring that teachers have carried out their duties properly is part of the school principal's responsibility.

One leadership type believed to balance the mindset and reflection of new views in the current of globalization formulated as transformational leadership. Transformational leadership patterns are as leadership that evokes or motivates subordinates to develop and achieve performance or a higher level so that they can achieve more than they previously thought (beyond expectation).

A transformational leader is who inspires his followers to go beyond their desires for the benefit of the organization (Robbins \& Judge, 2008). With transformational leadership, conducive, and comfortable team conditions and environments will be created for all team members (Suwandana, 2019). Through the transformational leadership model, all the potentials of learning organizations can be transformed into real ones to achieve the institution's goals; in this case, the school (Danim, 2005).

According to Bass \& Riggio (2006), there are three components in transformational leadership: charismatic-inspirational, intellectually stimulating, and individually considerate. Meanwhile, according to Bass and Avolio (Sunarsih, 2001) proposes four dimensions in the level of transformational leadership, namely: (1) Idealized Influenced or Charismatic, (2) Inspirational Motivation or Inspirational, (3) Intellectual Stimulation, (4) Individualized Consideration. The explanation above shows that the performance of a teacher is critical in ensuring the success of an educational process. Theoretically, several factors support the creation or improvement of teacher performance in carrying out their duties and responsibilities. These factors include work motivation, interpersonal communication, and transformational leadership. Based on this theory, the researcher wants to directly analyze the effect of transformational leadership, interpersonal communication, and work motivation on teacher performance at State Junior High Schools in Banjarmasin Utara. Besides, the researcher also wanted to analyze the influence of transformational leadership and interpersonal communication on teacher performance at State Junior High Schools in Banjarmasin Utara through work motivation.

Hopefully, this research can provide clear information about the effect of transformational leadership, interpersonal communication, and work motivation on teacher performance. Thus, policymakers can use the results of this study as a material consideration in designing programs or activities aimed at improving teacher performance.

\section{Material and Methods}

The study population was 299 people in State Junior High School in Banjarmasin Utara. The research sample was 171 teachers in 10 schools selected by proportional stratified random sampling. The calculation of the sample size is using the Slovin formula. Furthermore, the research data were collected using a five-scale questionnaire model. The efficacy and reliability of the questionnaire had previously been tested. The respondents filled out the questionnaire by giving a score between one to five, according to the respondents' actual conditions

This study used four questionnaires, namely the transformational leadership questionnaire, interpersonal communication questionnaire, working motivation questionnaire, and teacher performance questionnaire. The collected data was then tabulated and first tested using the prerequisite test for path analysis. The Parasyart test applied to this research data includes the normality test, homogeneity test, multi-questionnaire test, and heteroscedasticity test. After meeting the data requirement, it is then further testing the hypothesis using the path analysis test. The things tested are by the conceptual relationship model between the variables, as shown in Figure 1. 


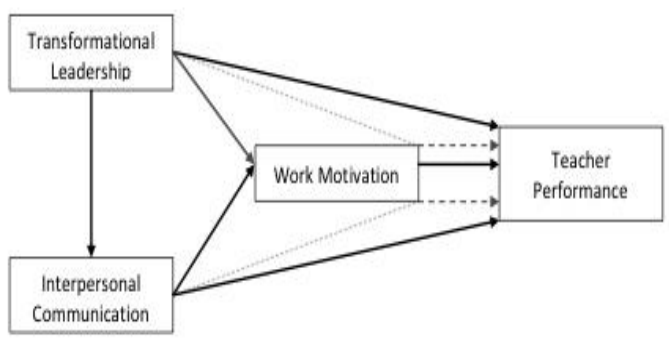

Figure 1. Research model

\section{Results and Discussion}

The descriptive statistical analysis of respondents from the research variable results in the name of transformational leadership, interpersonal communication, work motivation, and teacher performance measured on a scale of 5 shown in Table 1, which includes the meaning, standard deviation, and categories.

Descriptive data in Table 1 means that the respondent gives the highest emphasis on answering the research questionnaire on interpersonal communication. The classical assumption test results include the residual normality data test using the Kolmogorov-Smirnov one-sample method, which shows that all variables distribution are normal. The homogeneity test results show that all the variables used come from the same population or homogeneous variants. The multicollinearity test results showed that the tolerance value of each variable is more than 0.1, and the VIF value is more than 10. Besides, the results of the heteroscedasticity test on all variables showed a significance value of more than 0.05 .

After the test results of the analysis requirements have been met, the next step is to interpret the path analysis results with a summary of the results in Table 2 .

Table 1. Mean, standard deviation and category of research variables

\begin{tabular}{lccc}
\hline \multirow{2}{*}{ Variable } & \multicolumn{3}{c}{ Descriptive } \\
\cline { 2 - 4 } & Mean & Standard Deviation & Category \\
\hline Transformational leadership & 187.12 & 13.242 & High \\
\hline Interpersonal communication & 96.35 & 12.769 & Very high \\
\hline Work motivation & 175.60 & 13.409 & High \\
\hline Teacher performance & 215.05 & 13.014 & High \\
\hline
\end{tabular}

Table 2. Structure analysis result 1

\begin{tabular}{|c|c|c|c|c|}
\hline Variable & Dath confficiont & $t$ & Sig & $R^{2}$ \\
\hline Transformational leadership & 0.445 & 7.575 & 0.000 & \multirow{2}{*}{0.859} \\
\hline Interpersonal communication & 0.513 & 8.723 & 0.000 & \\
\hline \multirow[t]{2}{*}{ Variable } & & & Sig & $R^{2}$ \\
\hline & Path coefficient & $t$ & & \\
\hline Transformational leadership & 0.391 & 5.228 & 0.000 & \multirow{3}{*}{0.831} \\
\hline Interpersonal communication & 0.206 & 2.651 & 0.009 & \\
\hline Work motivation & 0.349 & 4.113 & 0.000 & \\
\hline
\end{tabular}


Table 4. Summary of hypothesis testing results H1, H2, H3, H4, H5

\begin{tabular}{lcc}
\hline \multicolumn{1}{c}{ Hypothesis } & $\boldsymbol{p}$ & Decision \\
\hline $\begin{array}{l}\text { Contribution of transformational leadership to work } \\
\text { motivation }\end{array}$ & 0.000 & Accepted \\
\hline $\begin{array}{l}\text { Contribution of transformational leadership to teacher } \\
\text { performance }\end{array}$ & 0.000 & Accepted \\
$\begin{array}{l}\text { There is a contribution of interpersonal communication to } \\
\text { work motivation }\end{array}$ & 0.000 & Accepted \\
\hline $\begin{array}{l}\text { Contribution of interpersonal communication to teacher } \\
\text { performance }\end{array}$ & 0.009 & Accepted \\
\hline $\begin{array}{l}\text { There is a contribution of teacher work motivation to teacher } \\
\text { performance }\end{array}$ & 0.000 & Accepted \\
\hline
\end{tabular}

Table 5. Summary of hypothesis testing results $\mathrm{H6}$ and $\mathrm{H} 7$

\begin{tabular}{|c|c|c|c|c|c|}
\hline \multirow[t]{2}{*}{ Hypothesis } & \multicolumn{2}{|c|}{ Path Coefficient } & \multicolumn{2}{|c|}{ Mediation effect } & \multirow{2}{*}{ Decision } \\
\hline & Direct & Indirect & $Z$ & Z Absolute & \\
\hline $\begin{array}{l}\text { There is a contribution of } \\
\text { transformational leadership to } \\
\text { teacher performance through } \\
\text { work motivation }\end{array}$ & 0.391 & 0.546 & 3.203 & 1.960 & Accepted \\
\hline $\begin{array}{l}\text { There is the contribution of } \\
\text { interpersonal communication to } \\
\text { teacher performance through } \\
\text { teacher work motivation }\end{array}$ & 0.206 & 0.361 & 2.179 & 1.960 & Accepted \\
\hline
\end{tabular}

The path analysis results, as shown in Table 2 and Table 3 are to answer the seven research hypotheses that have been formulated, and the results of the analysis shown in Table 3.4 and Table 5. Table 4 summarizes the decisions of hypotheses 1 through hypothesis 5 with critical values less than 0.05 , then the hypothesis is accepted. Table 5 summarizes the decisions on hypothesis testing 6 to hypothesis 7 , which are indirect contributions.

From the results of the hypothesis testing conducted, this study found that: (1) there is a significant direct effect of transformational leadership, work motivation, and interpersonal communication on teacher performance; (2) there is a transformational leadership and interpersonal communication significant influence on teacher work motivation; and (3) there is a transformational leadership and interpersonal communication significant effect on teacher performance through work motivation.

In general, leadership is a matter of relations and influence between the leader and the one being led (Dadda et al., 2019; Irwan et al., 2019).
Rivai (2014) states that leadership is defined as the ability and skills of a person in charge of a work unit to influence others' behavior, especially his subordinates. Thus, lead them to think and act in such a way that through positive behavior, he makes a real contribution to achieving organizational goals.

This leadership can function based on the leader's power to invite, influence, and mobilize other people to do something to achieve one specific goal (Mustanir et al., 2019). In the leadership context, someone needs to exert influence on others (Yulk, 2009). Furthermore, Kauzes dan Posner (2013) formulate five steps taken to become transformational leaders, namely: (1) Questioning current practices, (2) Inspiring a shared vision, (3) Helping others to act, (4) Demonstrating or practicing how to realize the new vision, and (5) Supporting wholeheartedly, the leadership function of the principal is guiding, guiding, guiding, giving work motivation, driving the organization, establishing better communication so that it will be able to bring followers to its goals that were planned. 
The success of the principal in carrying out his duties can be seen through his ability to create a teaching and learning climate, influence, and invite teachers, employees, and students to fulfill their respective duties as well as possible. Therefore, the principal's role is one of the critical factors in achieving school goals (Susanto, 2012).

According to Burns (1978), transformational leadership is a process in which leaders and followers raise themselves to high levels of morality and motivation. Transformational leadership can bring change in every individual involved and the whole organization to achieve higher performance (Wijaya \& Supardo, 2005). According to Aviolo, a transformational leader's primary function is to provide services as a catalyst for change and, at the same time, as a controller of change (Kaihatu \& Rini, 2007).

This study's results indicate that direct transformational leadership has a significant effect on teacher performance and is supported by several previous research results. Such research was conducted by Inayatillah, Abdurakhman, \& Aliyyah (2016), which found that transformational leadership is also proven to affect teacher performance directly. Similar results were also found by (2011). His research found that transformational leadership also had a positive and significant effect on teacher performance at Wijana Catholic Middle School Jombang.

At the primary school level, research conducted by (Sunarsih C., 2017) found that transformational leadership affects the performance positively and significantly of all public elementary school teachers in the Cimahi Utara Regency. Similar to this research, the results of a study conducted by Hutagaol (2016) also found something similar: that the implementation of transformational leadership by school principals has shown to have a positive direct effect on teachers' performance Ciracas Regency, East Jakarta. Furthermore, from this study, it was concluded that transformational leadership supports creating a conducive atmosphere so that the learning process can occur better and achieve optimal results. Research conducted by Andriani (2018) also proves that at the Vocational High School level, transformational leadership also positively and significantly affects the performance of State Vocational School teachers in Palembang City. This study found that transformational leadership also affected work motivation and was also supported by several previous research results. For example, a study conducted by Kuswaeri (2016) found that transformational leadership had a significant influence on Middle School teachers' work motivation in Sumedang Regency. Another study that showed the same results was the research conducted by Kumalasari (2009), which found that the principal's transformational leadership had a positive effect on teacher work motivation at Bina Amal Islamic Elementary School Semarang.

In terms of interpersonal communication, this study shows that interpersonal communication has a direct or indirect effect on teacher performance. These study findings are supported by previous research by Meva Ariyanti, namely "The Effect of Interpersonal Communication on Teacher Performance, and Work Motivation as an Intervening Variable (Study at State High School 01 Mukomuko)" which found that interpersonal communication has a significant influence on motivation. Besides, research conducted by Andana (2016) shows that interpersonal communication affects teacher performance with the conclusion that interpersonal communication has a positive effect on teacher performance.

The principal's interpersonal communication has also been proven to affect teacher performance at State Vocational High School 2 Tangerang Selatan (Hardiyanti, 2018). Other research also proves a similar thing where interpersonal communication contributes positively and significantly by $7.2 \%$ to the performance of Public Elementary School teachers in Pengasih Sub-district, Kulonprogo Regency (Ngatinah \& Purnami, 2019). And $29.2 \%$ for Public Elementary School teachers all over the Bantul sub-district (Parastika, 2016). Interpersonal communication was found to directly or indirectly affect the performance of state high school teachers in the Jepara Regency through work motivation as the mediation with a contribution of 5.0727 (Murniasih, Djunaidi, \& Rahardjo, 2016).

Research conducted by Setyana, Suntoro, \& Sumadi (2013) confirms that the performance of teachers at the Bodhisattva school in Bandar Lampung starts from Elementary School, Middle School, and High School is also influenced by interpersonal communication factors. Furthermore, 
Herlina (2018) also found that interpersonal communication and work motivation simultaneously positively affected the performance of public MTs teachers in Palembang City. Ruth (2017) has also proven that interpersonal communication skills and teaching motivation together have a significant effect on teacher performance at Trisoko High School and Pusaka 1 High School in East Jakarta.

From these results, interpersonal communication does have a significant role in supporting the performance of teachers. Communication is the delivery and reception of messages (Sutrisno, 2011), communication activities are the ability that must be possessed by a teacher to convey messages in the form of ideas or information to students and school residents to achieve the school's goals. Communication is understood as feedback that aims to help someone improve interpersonal effectiveness (De Vitto, 1998). Interpersonal communication from a leader in an organization is described as providing directions and suggestions by a leader in an atmosphere of intimacy, personal, and perhaps private and confidential (Yusuf, 2015).

From the results of this study and previous research, it can be understood that interpersonal communication significantly influences teacher performance. One form of communication that is very important is interpersonal communication or communication that occurs face-to-face between several individuals or individuals, allowing direct verbal and non-verbal responses. In operation, communication takes place reciprocally and produces feedback directly in response to a message. Two-way communication and direct feedback will allow for effective communication. In general, an effective communication process will result in good quality social relationships.

\section{Conclusion and Recommendation}

Analysis and the above explanation, this study concludes that: (1) there is a positive and significant effect directly from transformational leadership, interpersonal communication, and work motivation on teacher performance at State Junior High Schools in Banjarmasin Utara through work motivation. Furthermore, (2) there is a positive and significant effect of transformational leadership, interpersonal communication on teacher per- formance at State Junior High Schools in Banjarmasin Utara through work motivation. So, it is that the three variables, namely transformational leadership, interpersonal communication, and work motivation, have a crucial role in improving teacher performance. The higher the quality of transformational leadership implemented by the principal, the better the teacher's performance. The better the interpersonal communication created in school, the better the teacher's performance. Likewise, if the teacher's work motivation increases, the teacher's performance will be even higher.

Based on the results of this study, operationally, it is recommended that the Head of the Banjarmasin City Education Office carry out activities or programs that can assist school principals in improving the quality of implementing transformational leadership patterns and interpersonal communication. Activities and programs to increase teacher work motivation also need to be implemented.

It is hoped that the Principals of State Junior High Schools in Banjarmasin Utara Regency will always carry out their leadership by following the transformational leadership pole and always maintaining interpersonal communication with teachers. It always creates a conducive atmosphere in the school environment, which in turn can build work motivation for teachers who are at school.

It is recommended to research to test other independent variables that can affect teacher performance. This research will be indispensable to complement this research so that later it can be found all the factors that have a positive and significant effect on teacher performance. By obtaining complete information about the factors that have a positive and significant effect on teacher performance, the planning and implementation of programs and activities to improve teacher performance will be carried out better and, of course, will produce more optimal results. It will also significantly affect students' quality and learning outcomes because teacher work significantly affects student achievement.

\section{Acknowledgment}

The authors say thanks and appreciation go to Universitas Lambung Mangkurat, Banjarmasin and all parties involved and contributed in completing this research. 


\section{References}

Andana, A. P. (2016). The effect of interpersonal communication, motivation, and discipline on teacher's performance in SMA Muhammadiyah in Banyumas. Yogyakarta: UIN Sunan Kalijaga.

Andriani, S. (2018). The effect of transformational leadership and work motivation on teacher performance. Palembang: Universitas PGRI Palembang.

Ariyanti, M. (2016). The effect of interpersonal communication on the teacher's performance, and work motivation as an intervening variable (A study in SMA Negeri 01 Mukomuko). Jakarta: Universitas Terbuka.

Aw, S. (2011). Interpersonal communication. Yogyakarta: Graha Ilmu.

Bass, M. B., \& Riggio, E. R. (2006). Transformational leadership. New Jersey: Lawrence Erlbaum Associates, Inc.

Beltrán-Martín, I., \& Bou-Llusar, J. C. (2018). Examining the central role of employee abilities, motivation, and opportunities to participate in the relationship between HR bundles and employee performance. BRQ Business Research Quarterly, 21(2), 99-110. doi:https://doi.org/10.1016/j.brq.2018.02.001

Blazar, D., \& Kraft, M. A. (2017). Teacher and teaching effects on students' attitudes and behaviors. Educational Evaluation and Policy Analysis, 146-170.

Burns, J. M. (1978). Leadership. New York: Harper \& Row.

Dadda, D. A., Mustanir, A., Nilwana, A., \& Jamaluddin. (2019). The effect of female head village on the stability of social order and security in Rappang, Sidenreng Rappang. The $8^{\text {th }}$ National Conference of Postgraduate Program Association of University of Muhammadiyah Aisyiyah (APPPTMA) (pp. 378383). Medan: Postgraduate Program University of Muhammadiyah Yogyakarta. Retrieved from http://asosiasipascaptm.or.id/index.php/publikasi/prosidingkonferensi-nasional-appptma-ke-8

Danim, S. (2005). Transformational leadership in learning organization community (2 ed.). Jakarta: Bumi Aksara.

De Vitto, L. (1998). Interpersonal communication. New York: Herper and Row Publishing Co.

DeVito, J. A. (2013). Interpersonal communication book. London: Pearson.

Hardiyanti, S. (2018). The relation of principal interpersonal communication and teacher performance in SMKN 2 Tangerang Selatan. Jakarta: UIN Syarif Hidayatullah.

Henny Normianti, A. A. (2019). Relationship of transformational leaders of principal, teacher motivation, teacher organization commitments with performance of primary school teacher in Labuan Amas Selatan, Indonesia. European Journal of Education Studies.

Herlina. (2018). The effect of interpersonal communication and work motivation toward teacher performance of Public MTs in Palembang. Palembang: Universitas PGRI Palembang.
Herzbeg, F. (2017). Motivation to work. London: Routledge.

Hutagaol, S. (2016, January). The relation of principal transformational leadership and Teacher work motivation on performance of state elementary school teachers in Ciracas, Jakarta Timur. Jurnal Manajemen Pendidikan, 5(1), 52-81. Retrieved from http://ejournal.uki.ac.id/index.php/jmp/article/view/334

Inayatillah, S., Abdurakhman, O., \& Aliyyah, R. R. (2016, April). The effect of transformational leadership principal on the teacher performance at MA Miftahul Huda and MA Fathan Mubina. Ta'dibi, 5(1), 23-31.

Irwan, Latif, A., Sofyan, Mustanir, A., \& Fatimah. (2019, February). Leadership style, civil servant performance, and public participation in the development in Kulo Sub-district, Sidenreng Rappang Regency. Jurnal Moderat, 5(1), 32-43. Retrieved from https://jurnal.unigal.ac.id/index.php/moderat

Kaihatu, T. S., \& Rini, W. A. (2007, March). Transformational leadership and its effect on the satisfaction of work-life quality, organizational commitment, and extra-role behavior: A study on teachers of SMU in Surabaya. Jurnal Manajemen dan Kewirausahaan, 98(1), 49-61.

Kemelimeda, Hairudinor, Ridwan, M. N., \& Dalle, J. (2018). The effect of motivation, job satisfaction, and job discipline toward employee performance of PT Buma Perindahindo at LNG Tangguh Site, Teluk Bintuni Regency, West Papua, Indonesia. European Journal of Human Resource Management Studies, 2(1), 49-73. doi:10.5281/zenodo.2040456

Komariah, A., \& Triatna, C. (2005). Visionary leadership to effective school. Jakarta: Bumi Aksara.

Kouzes, J. M., \& Posner, B. Z. (2013). LPI: Leadership Practices Inventory. San Francisco: Pfeiffer.

Kumalasari, B. (2009). The effect of principal transformational leadership on teacher work motivation in SDIT Bina Amal Semarang. Semarang: State University of Semarang.

Kuswaeri, I. (2016). Contribution of transformational leadership of headmaster on the teacher's work motivation in SMP Kabupaten Sumedang. Tanzhim Jurnal Penelitian Manajemen Pendidikan, 1(1), 1-12.

Mahler, D., Großschedl, J., \& Harms, U. (2018). Does motivation matter? - The relationship between teachers' self-efficacy and enthusiasm and students' performance. Plos One, 13(11), e0207252. doi:https://doi.org/10.1371/journal.pone.0207252

Mulyasa, E. (2004). School based management. Bandung: PT Remaja Rosdakarya.

Munawaroh. (2011, July). The effect of transformational leadership and transactional leadership on teacher performance. Journal of Business Economics, 16(2), 136-144.

Murniasih, Y., Djunaidi, \& Rahardjo, T. J. (2016). The effect of academic supervision, interpersonal communication, and work motivation on teacher performance in Jepara. Educational 

$\begin{aligned} & \text { Management, } \quad \text { 5(2), } 148-155 . \quad \text { Retrieved from } \\ & \text { http://journal.unnes.ac.id/sju/index.php/eduman }\end{aligned}$

Mustanir, A., Ramadhan, M. R., Razak, M. R., Lukman, Sapri, \& Takhrim. (2019, June). The role of the Head of District and government communication on the development plan in Malua District, Enrekang Regency. Jurnal Ilmiah Clean Government, 2(2), 94-114.

Ngatinah \& Purnami, A. S. (2019, February). Contribution of interpersonal communication, emotional intelligence, and school organization commitment to elementary school teachers' performance. Sosiohumaniora, 5(1), 18-27.

Ofojebe \& Ezugoh. (2010, April). Teachers' motivation and its influence on quality assurance in the Nigerian educational system. African Research Review (An International Multi_disciplinary Journal Ethiopia), 4(2), 11-18.

Parastika, K. (2016). Contribution of interpersonal communication on performance of state elementary shool teachers in Bantul Sub-district. Yogyakarta: Universitas Negeri Yogyakarta.

Poernamawijaya, L. W., Sulaiman, S., Suriansyah, A., \& Dalle, J. (2018). Contribution to the supervision of the supervisor, principal motivation, and kindergarten teacher performance improves the kindergarten quality in West Banjarmasin, Indonesia. European Journal of Alternative Education Studies(3), 130-146. doi:10.5281/zenodo.2261031

Rahawarin, C., \& Arikunto, S. (2015). The effect of communication, organization climate, and principal transformational leadership style upon teacher performance of SMA. Jurnal Akuntabilitas Manajemen Pendidikan, 1(1), 11-19.

Ramdhani, M. A., \& Suryadi, K. (2005). Consensus method development on the analytic hierarchy process. International Conference on Quantitative Sciences and Its Applications 2005. Penang, Malaysia.

Rivai, V. Z. (2014). Leadership and organizational behavior. Jakarta: PT Raja Grafindo.

Robbins, S. P., \& Judge, T. A. (2008). Organizational behavior. Jakarta: Salemba.

Ruth, B. (2017). Interpersonal communication ability and teaching motivation toward teacher performance in Senior High School in Jakarta Timur. Therapeutic Journal of Guidance and Counseling, 1(1), 53-59. doi:https://doi.org/10.26539/1111

Setyana, M. E., Suntoro, I., \& Sumadi. (2013). The effect of principal academic supervision, interpersonal communication, and work motivation on teachers' performance $\mathrm{n}$ Bodhisattva school in Bandar Lampung. Journal of Educational Quality Management, 1(3), 112-118.

Siagian, S. P. (2012). Theory of motivation and its application. Jakarta: Rineka Cipta.
Sunarsih. (2001). Transformational leadership in organizational change era. Journal of Management and Business,2(1), 24-31.

Sunarsih, C. (2017, October). Transformational leadership of school principal and Teacher achievement motivation on teacher teaching performance. Journal of Education Administration, XXIV(2), 14-19.

Suriansyah, A. (2014). The relations among school culture, communication, and work commitment upon the performance of state elementary school teachers. Journal of Educational Horizon, 33(3), 358-367. doi:https://doi.org/10.21831/cp.v3i3.2380

Suriansyah, A., \& Aslamiah, A. (2012). Effective principal: From theory to practice. Banjarmasin: Rumah Pengetahuan.

Surya, M. (2003). Counseling psychology. Jakarta: Pustaka Bani Qurasisy.

Susanto, H. (2012, June). Factors influenced teachers' performance in Vocational High School. Jurnal Pendidikan Vokasi, 2(2), 197212.

Sutrisno, E. (2011). Human resources management. Jakarta: Kencana.

Suwandana, I. M. (2019, March). Role of transformational leadership mediation: Effect of emotional and communication intelligence towards teamwork effectiveness. International Research Journal of Management, IT \& Social Sciences, 6(2), 52-62. doi:https://doi.org/10.21744/irjmis.v6n2.608

Tuomi, K., Vanhala, S., Janhonen, M., \& Nykyri, E. (2005). Employees' workability and company performance: A followup study in the metal industry and retail trade. International Congress $\quad$ Series, $\quad 1280, \quad 234-237$. doi:https://doi.org/10.1016/j.ics.2005.02.057

Uhar, S. (2010). Education administration. Bandung: Refika Aditama.

Uno, H. B. (2011). Theory of motivation and its measurement: Analysis in education. Jakarta: Bumi Aksara.

Vosloban, R. I. (2012). The influence of the employee's performance on the company's growth - A managerial perspective. Procedia Economics and Finance, 3, 660-665. doi:https://doi.org/10.1016/S2212-5671(12)00211-0

Wibowo. (2014). Behavior in the organization. Jakarta: Raja Grafindo Persada.

Wijaya, B. R., \& Supardo, S. (2005). Leadership: Basics and its development. Yogyakarta: Andy.

Yulk, G. (2009). Leadership in organization. Jakarta: PT Indeks.

Yuniarsih, T., \& Suwatno. (2008). Human resources management. Bandung: Alfabeta.

Yusuf, Z. A. (2015). Communication management. Bandung: CV. Pustaka Setia. 